\title{
Anti-inflammatory and immunomodulatory effects of Aquaphilus dolomiae extract on in vitro models
}

This article was published in the following Dove Press journal:

Clinical, Cosmetic and Investigational Dermatology

10 November 2016

Number of times this article has been viewed

\author{
Marie-Françoise Aries' \\ Hélène Hernandez-Pigeon' \\ Clémence Vaissière ${ }^{\prime}$ \\ Hélène Delga' \\ Antony Caruana' \\ Marguerite Lévêque' \\ Muriel Bourrain ${ }^{1,2}$ \\ Katia Ravard Helffer' \\ Bertrand $\mathrm{Chol}^{3}$ \\ Thien Nguyen' \\ Sandrine Bessou-Touya' \\ Nathalie Castex-Rizzi' \\ 'Pierre Fabre Dermo-Cosmétique, \\ Centre de Recherche \& \\ Développement Pierre Fabre, \\ Toulouse, ${ }^{2}$ Sorbonne Universités, \\ UPMC Univ Paris 06, CNRS, \\ Laboratoire de Biodiversité et \\ Biotechnologies Microbiennes (LBBM), \\ Observatoire Océanologique, Banyuls/ \\ Mer, France; ${ }^{3}$ Centre d'Immunologie \\ Pierre Fabre, Saint-Julien-en-Genevois, \\ France
}

Correspondence: Nathalie Castex-Rizzi Pierre Fabre Dermo-Cosmétique, Centre de Recherche \& Développement Pierre Fabre - Toulouse Oncopôle, 3 Avenue

Hubert Curien - BPI3562 - 31035

Toulouse Cedex I, France

Tel +33534506000

Fax +33534503432

Email nathalie.castex.rizzi@pierre-fabre. com
Background: Atopic dermatitis (AD) is a common skin disease characterized by recurrent pruritic inflammatory skin lesions resulting from structural and immune defects of the skin barrier. Previous studies have shown the clinical efficacy of Avène thermal spring water in $\mathrm{AD}$, and a new microorganism, Aquaphilus dolomiae was suspected to contribute to these unique properties. The present study evaluated the anti-inflammatory, antipruritic, and immunomodulatory properties of ES0, an original biological extract of $A$. dolomiae, in immune and inflammatory cell models in order to assess its potential use in the treatment of AD.

Materials and methods: An ES0 extract containing periplasmic and membrane proteins, peptides, lipopolysaccharides, and exopolysaccharides was obtained from $A$. dolomiae. The effects of the extract on pruritus and inflammatory mediators and immune mechanisms were evaluated by using various AD cell models and assays.

Results: In a keratinocyte model, ES0 inhibited the expression of the inflammatory mediators, thymic stromal lymphopoietin, interleukin (IL)-18, IL-4R, IL-8, monocyte chemoattractant protein-3, macrophage inflammatory protein-3 $\alpha$, and macrophage-derived chemokine and induced the expression of involucrin, which is involved in skin barrier keratinocyte terminal differentiation. In addition, ES0 inhibited protease-activated receptor-2 activation in HaCaT human keratinocytes stimulated by stratum corneum tryptic enzyme and T helper type (Th) 1 , Th2, and Th17 cytokine production in Staphylococcal enterotoxin B-stimulated CD4+ lymphocytes. Lastly, ES0 markedly activated innate immunity through toll-like receptor (TLR) 2, TLR4, and TLR5 activation (in recombinant human embryonic kidney 293 cells) and through antimicrobial peptide induction (psoriasin, human beta-defensin-2, and cathelicidin), mainly through TLR5 activation (in normal human keratinocytes).

Conclusion: Overall, these in vitro results confirm the marked regulatory activity of this $A$. dolomiae extract on inflammatory and immune responses, which may be of value by virtue of its potential as an adjunctive treatment of $\mathrm{AD}$ inflammatory and pruritic lesions.

Keywords: atopic dermatitis, inflammation, anti-inflammation, in vitro and in vivo activities, barrier function, microorganism

\section{Introduction}

Atopic dermatitis (AD) is a common chronic skin disease characterized by recurrent pruritic inflammatory skin lesions resulting from a compromised skin barrier caused by genetically and environmentally determined structural defects and immune dysregulation. ${ }^{1-3}$ It was found that serine proteases can alter skin barrier function and contribute to inflammation and pruritus, primarily by activation of protease-activated receptor- 2 (PAR-2) and intracellular calcium mobilization. ${ }^{4}$ Skin barrier impairment leads to greater susceptibility to cutaneous infections, particularly by Staphylococcus aureus, submit your manuscript

Dovepress if in $D$


and increased allergen penetration. This, in turn, contributes to cutaneous inflammation, mediated by the expression of various proinflammatory factors including cytokines (thymic stromal lymphopoietin [TSLP] interleukin [IL]-18) and chemokines (IL-8, regulated upon activation, normal $\mathrm{T}$ cell expressed and secreted [RANTES], monocyte chemoattractant protein 3 [MCP3], and macrophage inflammatory protein $[\mathrm{MIP}]-3 \alpha$ ) and by the activation of keratinocytes, dendritic cells, and specific T-lymphocytes directed against exogenous or autoantigens. ${ }^{5,6}$

From various studies, it was found that keratinocytes express toll-like receptors (TLRs), which are a family of evolutionary conserved pattern recognition receptors (PRRs) involved in innate immunity. ${ }^{7,8}$ Each TLR senses specific microbial ligands and thus activates the innate immune system. Impairment of PRRs and an insufficient quantity of antimicrobial peptides (AMPs) to combat $S$. aureus are observed in patients with AD. ${ }^{9}$ In particular, TLR2, which recognizes $S$. aureus, is shown to be less expressed or altered in monocytes and macrophages of patients with AD. ${ }^{10-12}$ In addition, T helper type (Th) 1 and Th2 infiltration is enhanced in AD lesions. ${ }^{13}$ Indeed, although IL-17-producing cells (Th17) are more abundant in peripheral blood and acute AD lesions, Th2 cytokines inhibit Th17 response, leading to lower AMP expression by keratinocytes. ${ }^{3,14}$ In addition, Th2 cytokines also alter the barrier function by inhibiting the expression of keratinocyte terminal differentiation markers, such as involucrin. ${ }^{15}$

In recent years, several studies have shown the clinical efficacy of Avène thermal spring water in $\mathrm{AD}$, in particular immunomodulation of Th1-dependent and Th2-dependent cytokine production. ${ }^{16-21}$ In vitro experiments have also demonstrated multiple effects of Avène thermal spring water on numerous mediators involved in the immune response and on membrane fluidity, in addition to antiradical and antiinflammatory properties, and stimulatory effects on keratinocyte differentiation. ${ }^{22}$ An investigation of the deep aquifer of the Avène thermal spring water pointed out a new microorganism as a potential source of these unique properties due to its ability to modulate TLRs (data not shown). Based on its distinctive phenotypic and genotypic characteristics, this newly identified strain was assigned to a new genus, as a representative of a novel species called Aquaphilus dolomiae. It is a chemoorganotrophic non-spore-forming bacterium of the $\beta$-Proteobacteria class. ${ }^{23}$

In the present study, the activity of ES0, an original biological extract of $A$. dolomiae, on various AD-related mechanisms, including its effects on pruritus and inflammatory mediators, and on immune mechanisms in different immune and inflammatory cell models was evaluated. ${ }^{24}$

\section{Materials and methods \\ Materials \\ ESO extract}

ES0 extract (I-modulia ${ }^{\mathrm{T}}$, Pierre Fabre, Toulouse, France) was obtained from A. dolomiae, a novel nonpathogenic, chemoorganotrophic, non-spore-forming bacterium with a cell size of $2.3 \pm 0.3 \mu \mathrm{m}$ long and $1.0 \pm 0.1 \mu \mathrm{m}$ wide. A. dolomiae was isolated from aquifer water in the Cévennes mountains (France), as described previously in the study by Bourrain et al. ${ }^{23}$ Fermentation and purification were performed at Centre d'Immunologie Pierre Fabre (Saint-Julien-enGenevois, France) in accordance with pharmaceutical Good Manufacturing Practice as follows: A. dolomiae bacteria were cultivated in complex medium (ie, citric acid, magnesium sulfate, ammonium chloride, dipotassium phosphate, pyruvic acid sodium salt, yeast extract, glucose, and traces of OligoMix ${ }^{\circledR}$ ) under aerobic conditions at $27^{\circ} \mathrm{C}$ and $\mathrm{pH} 7.0$. The culture was carried out in three successive steps from a 1-L Erlenmeyer flask to a 350-L stirred fermenter. Highcell-density fermentation was carried out in fed-batch mode with a sterile glucose solution. Cell growth was monitored by using optical density (OD) measurements at $620 \mathrm{~nm}$ and dry cell weight determination. At the end of the fed-batch fermentation, bacterial cells were processed in an aqueous basic Tris buffer ( $\mathrm{pH} \mathrm{11)} \mathrm{containing} \mathrm{Arginine} \mathrm{at} 300 \mathrm{mM}$. After incubation under stirring for $5 \mathrm{~h}$ at a temperature of $4^{\circ} \mathrm{C}$, the cellular debris was removed by centrifugation on a disk separator followed by depth filtration. The clarified extract was filtered on a $0.2 \mu \mathrm{m}$ polyethersulfone filter. This extract contains periplasmic and membrane proteins, peptides, lipopolysaccharides, and exopolysaccharides.

\section{Methods}

\section{Evaluation of ESO activity on an AD keratinocyte model}

Normal human keratinocytes (NHKs) were prepared from skin flaps originating from plastic surgery (breast reduction, after obtaining the patients' informed consent according to the principles of the Declaration of Helsinki). French regulations (authorization is given by the French Ministry of Research [Decree $n^{\circ}$ 2007-1220]) do not require ethical committee approval for the sampling of organ tissues for use in research studies. The cells were cultured in keratinocyte serum-free medium (KSFM; Gibco ${ }^{\circledR}$, Life Technologies, Villebon-sur-Yvette, France) with low calcium content (0.1 $\mathrm{mM}$ ) supplemented by $25 \mu \mathrm{g} / \mathrm{mL}$ bovine pituitary extract $\left(\right.$ Gibco $\left.^{\circledR}\right)$ and $1.5 \mathrm{ng} / \mathrm{mL}$ epidermal growth factor $\left(\mathrm{Gibco}^{\circledR}\right)$.

Polymerase chain reaction (PCR) array analysis was conducted as previously described in a model of $\mathrm{AD}$ 
induction in NHK. ${ }^{25,26}$ Briefly, NHK were stimulated for 24 $\mathrm{h}$ with $10 \mu \mathrm{g} / \mathrm{mL}$ polyinosinic/polycytidylic acid (poly I:C) and $3 \mathrm{ng} / \mathrm{mL}$ of each cytokine, tumor necrosis factor alpha (TNF $\alpha$ ), IL-4, and IL-13 (R\&D Systems, Lille, France). In order to characterize the pattern of mRNA expression in the present model of stimulated NHK, the expression of $23 \mathrm{mRNA}$, including $21 \mathrm{mRNA}$ encoding various factors known to be differentially regulated in $\mathrm{AD}$, such as for inflammation and keratinocyte differentiation mediators, and two housekeeping genes (RPL13A and GAPDH) were studied. ${ }^{27}$ The relative quantity of mRNA expression after stimulation with poly I:C and cytokines was calculated compared with that obtained from unstimulated NHK using the formula $2^{-\Delta \Delta \mathrm{Ct}}$ were $\Delta \mathrm{Ct}=\mathrm{Ct}_{\text {gene of interest }}-\mathrm{Ct}_{\text {housekeeping gene }}$ and $\Delta \Delta \mathrm{Ct}=\Delta \mathrm{Ct}$ treated - $\mathrm{DCt}_{\text {control }}$. In order to evaluate the effects of ES0, PCR analysis was conducted after a 24-h incubation of the $\mathrm{AD}$ cellular model with ES0 10,30 , or $60 \mu \mathrm{g} / \mathrm{mL}$ or with the glucocorticoid dexamethasone (DEX; Sigma-Aldrich, Lyon, France) of $2 \mu \mathrm{M}$ (positive control), using SYBR Green probes specific to the chosen mRNA (Table S1). The relative quantity of mRNA expression after incubation of the AD model with ES0 was calculated, compared with the AD cellular model. It was also found, using a colorimetric MTT (bromure de 3-(4,5-dimethylthiazol-2-yl)-2,5-diphenyl tetrazolium) assay, that ES0 extract was not cytotoxic at the concentrations studied. ${ }^{28}$ Statistical analyses were conducted by using unpaired $t$-test on $\Delta \mathrm{Ct}$ results, in order to compare stimulated cells with unstimulated cells or treated cells with stimulated cells.

\section{Evaluation of ESO activity on PAR-2 assay}

The spontaneously immortalized $\mathrm{HaCaT}$ human keratinocyte cell line was cultivated in Dulbecco's Modified Eagle's Medium (DMEM; Gibco $^{\circledR}$ ) with $10 \%$ fetal calf serum (FCS; Gibco $^{\circledR}$ ) as previously described by Boukamp et al..$^{29}$ PAR-2 was first activated in $\mathrm{HaCaT}$ keratinocytes by stratum corneum tryptic enzyme (SCTE; R\&D Systems), leading to intracellular calcium flux. The inhibitory activity of ES0 on PAR-2 was assessed by measuring the intracellular calcium flux before and after the addition of ESO $\mathrm{HaCaT}$ cells were incubated for $30 \mathrm{~min}$ with a fluorescent probe esterified by an acetoxymethyl group (Fluo-4/AM; Molecular Probes ${ }^{\circledR}$, ThermoFisher Scientific, Villebon Sur Yvette, France; $2 \mu \mathrm{M}$ ) in a 96-well plate and then for $30 \mathrm{~min}$ alone or in the presence of ES0 ( 30 and $100 \mu \mathrm{g} / \mathrm{mL}$ ), before the injection of SCTE $50 \mathrm{nM}$. Intracellular calcium flux was assessed for $175 \mathrm{~s}$ by measuring the fluorescence emitted at $535 \mathrm{~nm}$ by the deesterified $\mathrm{Ca}^{2+}$-bound form of the probe, which is the only form excitable at $485 \mathrm{~nm}$. The microplate was read by Mithras LB940 ${ }^{\mathrm{TM}}$ (Berthold Technologies, Thoiry, France).

\section{Evaluation of ESO activity on TLR assay}

Human embryonic kidney (HEK; Invivogen, Toulouse, France) 293 cells were cultivated in $4.5 \mathrm{~g} / \mathrm{L}$ D-glucose + pyruvate supplemented with DMEM with $10 \%$ FCS, in the presence of Normocin ${ }^{\mathrm{TM}}$. HEK 293 cells were used as they functionally overexpress human TLR2, TLR4, or TLR5 proteins as well as a reporter gene, which is a secreted alkaline phosphatase (SEAP) expressed under the control of a nuclear

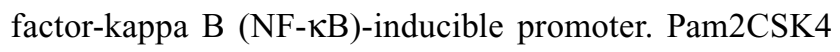
(TLR2 ligand) at $0.03,0.1,0.3$, and $1 \mathrm{ng} / \mathrm{mL}$; lipopolysaccharide (LPS) 0111 (TLR4 ligand) at $0.3,1,3$, and $10 \mathrm{ng} / \mathrm{mL}$; and flagellin (TLR5 ligand) at $1,3,10$, and $30 \mathrm{ng} / \mathrm{mL}$ were used as positive controls to induce HEK 293-hTLR2, HEK 293-hTLR4, and HEK 293-hTLR5 cell lines (InvivoGen, Toulouse, France), respectively. The negative control constituted a recombinant HEK 293 cell line for the SEAP reporter gene under the control of a NF- $\mathrm{\kappa B}$-inducible promoter only.

ES0 was diluted at 3,10,30, and $100 \mathrm{ng} / \mathrm{mL}$ in limulus amebocyte lysate water (Bio-Whittaker, Lonza, Levallois Perret, France), and $20 \mu \mathrm{L}$ of each sample and the respective control were used to stimulate HEK 293 TLR2-, TLR4-, and TLR5-expressing cell lines for $20 \mathrm{~h}$ in $200 \mu \mathrm{L}$ of final reaction volume. Activation of TLR2, TLR4, and TLR5 was measured by spectrophotometry, and the results were given as OD and percentage activity compared with nontreated cells for the highest ES0 concentration. All the experiments were performed in triplicate; the results were expressed as mean \pm standard deviation (SD) for each treatment.

\section{Evaluation of ESO on AMPs expression}

NHK were incubated for $24 \mathrm{~h}$ alone (negative control) or with IL-1 $\beta$ (R\&D Systems) $20 \mathrm{ng} / \mathrm{mL}$ (positive control), flagellin $100 \mathrm{ng} / \mathrm{mL}$ (TLR5 ligand from InvivoGen), or ES0 $6.5 \mu \mathrm{g} / \mathrm{mL}$. Blocking anti-TLR2, anti-TLR4, and anti-TLR5 antibodies from InvivoGen $(1 \mu \mathrm{g} / \mathrm{mL})$ were preincubated for $1 \mathrm{~h}$ before the addition of the test products. Cells were harvested, and the QuantiGene Plex 2.0 system (Ozyme, Saint Quentin en Yvelines, France) was used to quantify the mRNA expression of AMPs (human beta-defensin-2 [hBD-2], CAMP, psoriasin) directly from cell lysates. The assay was performed in accordance with the manufacturer's instructions. Data were exported to Microsoft Excel (Microsoft Corporation, Redmond, WA, USA), where background subtraction and normalization to two housekeepers (hypoxanthine phosphoribosyltransferase and polymerase [RNA] II polypeptide A) were performed. An effect of the test product on AMP expression was considered when the relative quantity of mRNA (calculated compared with the negative control) was $\geq 2$ (induction) or $\leq 0.5$ (inhibition). 


\section{Evaluation of ESO activity on adaptive immunity}

Peripheral blood mononuclear cells were obtained from three donors (French Blood Service, Pyrénées-Méditerranée, France). This was obtained under agreement number with French Blood Service 21/PLER/TOU/PF01/2013-0023. Written informed consent was also obtained. The cells were isolated from buffy-coat blood samples. Human CD4+ lymphocytes were purified by positive magnetic immunoselection (Miltenyi Biotec SAS, Paris, France). Lymphocytes were cultured in Roswell Park Memorial Institute 1640 medium with GlutaMax ${ }^{\mathrm{TM}} \mathrm{I}$ and $5 \% \mathrm{FCS}$ at $37^{\circ} \mathrm{C}$ in $5 \% \mathrm{CO}_{2}$ atmosphere. After incubation of CD4+ cells with Staphylococcal enterotoxin B (SEB) of $300 \mathrm{ng} / \mathrm{mL}$ and ES0 of 30, 60, and 100 $\mu \mathrm{g} / \mathrm{mL}(\mathrm{n}=3$ ) for $20 \mathrm{~h}$, culture supernatants were collected, centrifuged $\left(3000 \mathrm{rpm}, 15 \mathrm{~min}, 4^{\circ} \mathrm{C}\right)$, and frozen at $-20^{\circ} \mathrm{C}$ before proceeding to Th1 (IL-2, IFN- $\gamma$, IL-12, IL-1 $\beta$, and TNF $\alpha$ ), Th2 (IL-4 and IL-10), and Th17 (IL-17) cytokine immunoassay by the Luminex ${ }^{\mathrm{TM}}$ method using the Bio-Plex Pro $^{\circledR}$ Human Cytokine group 8-PLEX multiplex, in accordance with the supplier's instructions (Bio-Rad, Hercules, CA, USA). For each parameter, the results were expressed as mean $\pm \mathrm{SD}$.

\section{Statistical analysis}

Statistical evaluation of between-group comparisons was performed by one-way analysis of variance and Dunnett's test using Graph Pad Prism. For all the analyses, a difference with $P<0.05$ was considered significant.

\section{Results}

\section{Poly I:C-,TNF $\alpha-$, IL-4-, and IL-I3-stimulated NHK: an AD keratinocyte model}

PCR array analysis of the expression of 21 mRNA, known to be differentially regulated in $\mathrm{AD}$, after $24 \mathrm{~h}$ stimulation with poly I:C, TNF $\alpha$, IL-4, and IL-13 demonstrated similarities with the regulation of expression observed in $\mathrm{AD}$ in this in vitro model. Indeed, a markedly increased expression of eight chemokines, five cytokines, and one cytokine receptor normally upregulated in $\mathrm{AD}$ and a markedly lower expression of three downregulated keratinocyte differentiation markers were observed. In particular, the two cytokines, IL-18 and TSLP, were increased by twofold and 12-fold, respectively, and the chemokines, MCP3/CC chemokine ligand (CCL) 7, macrophage-derived chemokine (MDC)/CCL22, MIP-3 $\alpha /$ (CCL20), and IL-8 by eightfold and more than 30-, 200-, and 700 -fold, respectively (Table 1).

\section{Anti-inflammatory effects of ESO in stimulated $\mathrm{NHK}$}

The effect of ES0 on the regulation of mRNA involved in inflammation was assessed by comparing the effect of incubating stimulated NHK with ES0 or the positive control, DEX. First, it was confirmed that there was no cytotoxicity of the ES0 extract at the concentrations studied with MTT assay analysis (Table 2). Compared with control, NHK were completely viable $(104 \%-105 \%)$ in the presence of ES0 $1.1-100 \mu \mathrm{g} / \mathrm{mL}$; however, cell viability was reduced to $16 \%$ with ES0 $300 \mu \mathrm{g} / \mathrm{mL}$ and was lost (2\%) at ES0 $900 \mu \mathrm{g} / \mathrm{mL}$.

Compared with DEX, which regulated nine mediators, ES0 regulated 14 AD-related targets with a dose-effect relationship. Among the $21 \mathrm{mRNA}$ considered, three were upregulated by ES 0 and 11 were downregulated (Table 1). In particular, ES0 induced the involucrin keratinocyte differentiation marker by up to 11 -fold at a concentration of $60 \mu \mathrm{g} / \mathrm{mL}$ versus 1.1-fold for DEX of $2 \mu \mathrm{M}$; ES0 also induced RNASE7 and psoriasin AMPs by up to fivefold and 21-fold, respectively, versus 0.30 - and 0.46 -fold for DEX of $2 \mu \mathrm{M}$ (Table 1 ). On the other hand, the concentration of $60 \mu \mathrm{g} / \mathrm{mL}$ of ES0 reduced the expression of the two inflammatory cytokines TSLP and IL-18 by 0.08 -fold and 0.35 -fold and that of the four chemokines MCP3/CCL7, MDC/CCL22, MIP-3 $\alpha / C C L 20$, and IL-8 by $0.12-, 0.42-, 0.20$-, and 0.12 -fold compared with the stimulated NHK model, respectively (Table 1 ).

\section{PAR-2 inhibition by ESO}

Another cell model was used to evaluate the inhibitory effect of ES0 on the pruritus mediator, PAR-2. First, PAR-2 was activated in $\mathrm{HaCaT}$ keratinocyte cells by SCTE, leading to intracellular calcium flux. Then, the inhibition of PAR-2 by ES0 was assessed by measuring the intracellular calcium flux before and after the addition of ES0. ES0 dose-dependently inhibited SCTE-activated PAR-2 receptors (Figure 1). A significant effect was observed from a concentration of $30 \mu \mathrm{g} / \mathrm{mL}$ ( $P \leq 0.05$ vs SCTE only), and inhibition was greater at $100 \mu \mathrm{g} / \mathrm{mL}$, with a $50 \%$ decrease in SCTE-induced stimulation $(P \leq 0.001)$.

\section{Immunomodulatory activity of ESO Induction of TLR activation}

Evaluation of the immunomodulatory effect of ES0 on TLR activity was performed by TLR assay in stably transfected HEK 293 cell lines that overexpressed human TLR2, TLR4, or TLR5 proteins. Pam2CSK4 (TLR2 ligand), LPS 0111 (TLR4 ligand), and flagellin (TLR5 ligand) were used as positive controls to induce the hTLR2, hTLR4, and hTLR5 
Table I PCR array analysis of the expression of 21 genes

\begin{tabular}{|c|c|c|c|c|c|}
\hline \multirow[t]{2}{*}{ Biological markers } & \multirow{2}{*}{$\begin{array}{l}\text { Regulation of } \\
\text { gene expression in } \\
\text { 24-h-activated NHK }\end{array}$} & \multicolumn{3}{|c|}{$\begin{array}{l}\text { Effect of ESO on gene expression of 24-h-activated } \\
\text { NHK }\end{array}$} & \multirow{2}{*}{$\begin{array}{l}\text { Effect of DEX on } \\
\text { gene expression } \\
\text { of } 24 \text {-h-activated } \\
\text { NHK } \\
2 \mu \mathrm{M} \\
\end{array}$} \\
\hline & & $10 \mu \mathrm{g} / \mathrm{mL}$ & $30 \mu \mathrm{g} / \mathrm{mL}$ & $60 \mu \mathrm{g} / \mathrm{mL}$ & \\
\hline $\begin{array}{l}\text { Thymic stromal } \\
\text { lymphopoietin (TSLP) }\end{array}$ & $12.6 \pm 1.4 * * *$ & $0.44 \pm 0.04 * * *$ & $0.25 \pm 0.02 * * *$ & $0.08 \pm 0.02 * * *$ & $0.08 \pm 0.02 * * *$ \\
\hline Interleukin I, alpha (ILIA) & $35 \pm 1.4 * * *$ & $0.65 \pm 0.02 * *$ & $0.54 \pm 0.04 * *$ & $0.44 \pm 0.09 * *$ & $0.42 \pm 0.08 * * *$ \\
\hline Interleukin I8 (ILI8) & $2 \pm 0.1 * * *$ & $0.73 \pm 0.06 *$ & $0.57 \pm 0.03 * *$ & $0.37 \pm 0.09 * *$ & $0.5 I \pm 0.1 * *$ \\
\hline Interferon, alpha 2 (IFNA2) & $2.5 \pm 0.4 * * *$ & $I . I \pm 0.05$ & $1.16 \pm 0.31$ & $1.1 \pm 0.3$ & $0.57 \pm 0.2 I^{*}$ \\
\hline Interferon, beta I (IFNBI) & $24.3 \pm 1.5^{* * *}$ & $0.35 \pm 0.08 * * *$ & $0.18 \pm 0.01 * * *$ & $0.1 \pm 0.02 * * *$ & $0.46 \pm 0.09 * *$ \\
\hline Interleukin 8 (IL8) & $732 \pm 155^{* * * *}$ & $0.65 \pm 0.17 *$ & $0.47 \pm 0.08 * *$ & $0.13 \pm 0.08 * * *$ & $0.24 \pm 0.08 * * *$ \\
\hline MIP-I $\alpha(C C L 3)$ & $5759 \pm 2977 * * *$ & $0.9 \pm 0.06$ & $0.57 \pm 0.04 * *$ & $0.27 \pm 0.06 * * *$ & $0.21 \pm 0.04 * * *$ \\
\hline RANTES (CCL5) & $|559| \pm|44| * * *$ & $0.85 \pm 0.03$ & $0.57 \pm 0.04 * *$ & $0.37 \pm 0.07 * *$ & $0.8 \pm 0.15$ \\
\hline MCP-3 (CCL7) & $7.8 \pm 2.4^{* * *}$ & $0.61 \pm 0.18^{*}$ & $0.40 \pm 0.13 * *$ & $0.14 \pm 0.07 * * *$ & $\mathrm{I} . \mathrm{II} \pm 0.22$ \\
\hline TARC (CCLI7) & $21.5 \pm 6.2 * * *$ & $0.44 \pm 0.08 * *$ & $0.37 \pm 0.03 * *$ & $0.67 \pm 0.17$ & $I .1 I \pm 0.21$ \\
\hline MIP-3 $\alpha$ CCL20 & $212 \pm 17 * * *$ & $0.6 \pm 0.04 * *$ & $0.4 \pm 0.03 * * *$ & $0.21 \pm 0.04 * * *$ & $0.54 \pm 0.11 *$ \\
\hline MDC (CCL22) & $33.1 \pm 4.2 * * *$ & $0.84 \pm 0.03$ & $0.56 \pm 0.04 * *$ & $0.45 \pm 0.09 * *$ & $0.5 \pm 0.09 * *$ \\
\hline Skinkine (CCL27) & $57.8 \pm 0.7 * * *$ & $0.72 \pm 0.03 *$ & $0.68 \pm 0.05 *$ & $0.65 \pm 0.13$ & $0.37 \pm 0.07 * * *$ \\
\hline $\begin{array}{l}\text { Interleukin } 4 \text { receptor } \\
\text { (IL4R) }\end{array}$ & $6.3 \pm 0.6 * * *$ & $0.7 \pm 0.03 *$ & $0.56 \pm 0.04 * *$ & $0.32 \pm 0.07 * *$ & $0.23 \pm 0.05 * * *$ \\
\hline $\begin{array}{l}\text { Cathelicidin antimicrobial } \\
\text { peptide (CAMP) }\end{array}$ & $5.7 \pm 0.8 * * *$ & $1.1 \pm 0.1$ & $1.3 \pm 0.2$ & $1.8 \pm 0.4^{*}$ & $0.42 \pm 0.08^{* *}$ \\
\hline $\begin{array}{l}\text { Ribonuclease, RNase A } \\
\text { family, } 7 \text { (RNASE7) }\end{array}$ & $7.7 \pm 0.1 * * *$ & $2.4 \pm 0.1 * * *$ & $3.5 \pm 0.2 * * *$ & $5.3 \pm 1.1 * * *$ & $0.27 \pm 0.05 * * *$ \\
\hline $\begin{array}{l}\text { SI00 calcium binding } \\
\text { protein AII (SI00AII) }\end{array}$ & $3 \pm 0.1 * * *$ & $0.88 \pm 0.03$ & $0.88 \pm 0.06$ & $0.84 \pm 0.18$ & $0.6 \pm 0.11 *$ \\
\hline Psoriasin (SI00A7) & $16.6 \pm 0.2 * * *$ & $4.6 \pm 0.2 * * *$ & $\mid \mathrm{I} .4 \pm I^{* * * *}$ & $22.5 \pm 5.1 * * *$ & $0.42 \pm 0.08^{* *}$ \\
\hline $\begin{array}{l}\text { Ceramide synthase } 6 \\
\text { (CERS6) }\end{array}$ & $0.26 \pm 0.0 * * *$ & $0.94 \pm 0.04$ & $0.95 \pm 0.16$ & $0.93 \pm 0.23$ & $1.3 \pm 0.2$ \\
\hline Involucrin (IVL) & $0.18 \pm 0.0 * * *$ & $1.6 \pm 0.1 * *$ & $4.2 \pm 0.34 * * *$ & II. $8 \pm 2.4 * * *$ & $0.98 \pm 0.18$ \\
\hline Filaggrin (FLG) & $0.24 \pm 0.01 * * *$ & $1.02 \pm 0.04$ & $0.83 \pm 0.05$ & $0.74 \pm 0.15$ & $1.47 \pm 0.27 * *$ \\
\hline
\end{tabular}

Notes: NHKs were incubated with $10 \mu \mathrm{g} / \mathrm{mL}$ poly I:C $+3 \mathrm{ng} / \mathrm{mL}$ of each cytokine (TNF $\alpha+$ IL-4 + IL-13). NHKs were exposed to three different doses of ESO (I0, 30, and $60 \mu \mathrm{g} / \mathrm{mL}$ ) for $24 \mathrm{~h}$ compared with DEX of $2 \mu \mathrm{M}$. Relative quantity \pm SE of mRNA expression compared to control cells (for $24 \mathrm{~h}$-activated NHK) or to $2 \mathrm{~h}$-activated NHKs (for the effect of ESO or DEX). Data presented as mean \pm standard deviation. $* P<0.05 ; * * P<0.01 ; * * * P<0.001$.

Abbreviations: DEX, dexamethasone; ESO, extract from Aquaphilus dolomiae; IL, interleukin; NHK, normal human keratinocyte; PCR, polymerase chain reaction; SE, standard error; TNF $\alpha$, tumor necrosis factor alpha.

Table 2 Effect of ESO on normal human keratinocyte cell viability: MTT assay

\begin{tabular}{|c|c|c|}
\hline & $\begin{array}{l}\text { Treatment } \\
(24 \mathrm{~h} ; \mu \mathrm{g} / \mathrm{mL})\end{array}$ & $\begin{array}{l}\text { Cell viability (percentage } \\
\text { of control } \pm \text { SE) }\end{array}$ \\
\hline Control & & $100 \pm 2$ \\
\hline \multirow[t]{8}{*}{ ESO } & I.I & $104 \pm 3$ \\
\hline & 3.3 & $105 \pm 4$ \\
\hline & 10 & $106 \pm 4$ \\
\hline & 30 & $107 \pm 4$ \\
\hline & 60 & $105 \pm 5$ \\
\hline & 100 & $105 \pm 4$ \\
\hline & 300 & $16 \pm 1$ \\
\hline & 900 & $2 \pm 0$ \\
\hline
\end{tabular}

Abbreviations: $\mathrm{ESO}$, extract from Aquaphilus dolomiae; $\mathrm{SE}$, standard error.

cell lines, respectively. Following the incubation of the three HEK 293 TLR2-, TLR4-, and TLR5-expressing cell lines with various dilutions of ES0, measurement of TLR2, TLR4, and TLR5 activation by spectrophotometry showed that ES0 statistically significantly and dose-dependently $(10-100 \mathrm{ng} / \mathrm{mL})$ activated TLR2 $(P<0.001$ vs control; $+351 \%[\mathrm{OD}=2.45]$ at $100 \mathrm{ng} / \mathrm{mL}$ ) and TLR5 (at 3, 10, and $100 \mathrm{ng} / \mathrm{mL} ; P<0.001$ vs control; $+317 \%$ [OD $=1.04]$ at $100 \mathrm{ng} / \mathrm{mL}$; Figure 2$)$. ES0 also significantly $(P<0.001$ vs control) activated TLR4 at 3 and $10 \mathrm{ng} / \mathrm{mL}(+75 \%$ [OD $=0.8]$; Figure 2).

\section{Induction of antimicrobial peptides expression}

Compared with $24 \mathrm{~h}$ incubation of NHK alone (negative control), incubation with IL-1 $\beta 20 \mathrm{ng} / \mathrm{mL}$ (positive control) significantly induced the expression of the AMPs, hBD-2 $(P<0.05)$, cathelicidin CAMP (LL-37; $P<0.01)$, and psoriasin $(P<0.001$; Figure 3$)$. Similarly, incubation with ES0 of $6.5 \mathrm{mg} / \mathrm{mL}$ significantly induced the expression of hBD-2 $(P<0.05)$, CAMP $(P<0.01)$, and psoriasin $(P<0.001)$, whereas flagellin of $100 \mathrm{ng} / \mathrm{mL}$ (TLR5 ligand) 


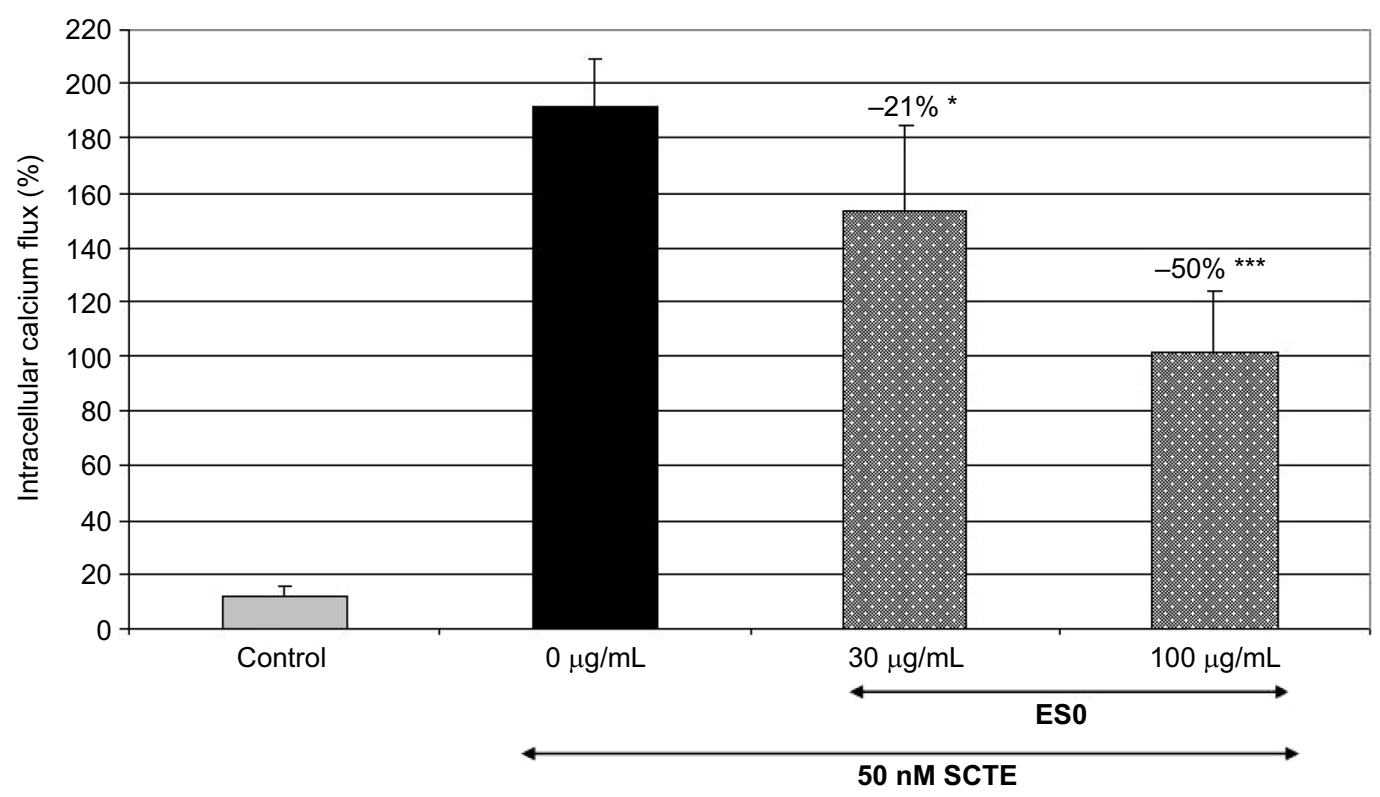

Figure I Stimulation of PAR-2 receptors by SCTE in HaCaT keratinocyte cells.

Notes: Dose-dependent inhibition by ESO (30 and $100 \mu \mathrm{g} / \mathrm{mL})$. $* P<0.05 ; * * * P<0.00$ I versus SCTE; data are representative of three independent experiments. Abbreviations: ESO, extract from A. dolomiae; PAR-2, protease-activated receptor-2; SCTE, stratum corneum tryptic enzyme.

markedly (hBD-2) or significantly (CAMP and psoriasin) induced these AMPs.

In addition, in order to test whether activation was mediated by TLR2, TLR4, or TLR5, the cells were preincubated with anti-TLR2, anti-TLR4, and anti-TLR5 antibodies $(1 \mu \mathrm{g} / \mathrm{mL})$ before the addition of the test products. The effect of flagellin was completely inhibited by the anti-TLR 5 antibody and partially reduced by anti-TLR2, whereas the effect of ES0 was partially inhibited by the anti-TLR5 antibody but was not affected by anti-TLR2 or anti-TLR4 antibodies. These results suggest that ES0 activated AMP expression in keratinocytes through TLR5 receptor activation.

\section{Inhibition of lymphocyte cytokines production}

In order to assess the effect of ES0 on cytokine production, fresh human CD4+ lymphocytes were incubated with SEB $(300 \mathrm{ng} / \mathrm{mL})$ to induce Th1, Th2, and Th17 cytokine production. Various doses of ES0 were added to the culture before proceeding with the cytokine immunoassay. ES0 dose-dependently inhibited Th1, Th2, and Th17 cytokines produced by CD4+ lymphocytes. ES0 inhibited four of eight targets at $30 \mu \mathrm{g} / \mathrm{mL}$ (IL-2, IL-12, IL-10, and IL-17) and all at $100 \mu \mathrm{g} / \mathrm{mL}$ (IL-2, IFN- $\gamma$, IL-12, IL-1 $\beta$, TNF $\alpha$, IL-4, IL-10, and IL-17; Figure 4). The percentage inhibition with ES0 of $100 \mu \mathrm{g} / \mathrm{mL}$ ranged from $-42 \%$ for IL-4 to $-95 \%$ for IL- 12 .

\section{Discussion}

The active ingredients present in ES0, an A. dolomiae extract, have not been characterized further; however, different batches of this extract exhibited reproducible activity in each of the cell models used in this study. Our results showed that this extract exerted marked regulatory activity on different mechanisms involved in the pathophysiology of AD, including keratinocyte inflammation, skin barrier impairment, and innate and adaptive lymphocyte immune responses.

In the present study, it was first established that NHK stimulated for $24 \mathrm{~h}$ with poly I:C and cytokines (TNFo, IL-4, and IL-13) constituted a model mimicking an "AD-like" condition. ${ }^{26}$ Indeed, keratinocyte differentiation markers such as involucrin, which were decreased in the present study, are important for skin barrier formation and integrity. Involucrin expression is significantly decreased in both acute and nonlesional skin of subjects with $\mathrm{AD}$ compared with skin from healthy subjects. ${ }^{15}$ Furthermore, all the inflammatory markers induced in the present in vitro model of stimulated NHK have been shown to be upregulated in $\mathrm{AD}$, for example, TSLP and IL-18 cytokines. ${ }^{25,30}$

TSLP was associated with the recruitment and activation of Langerhans cells in situ, suggesting its involvement in the early steps of allergic inflammation in the skin, and recently, it was found that TSLP plays a key role in the "atopic march" leading from $\mathrm{AD}$ to allergic asthma. ${ }^{31,32} \mathrm{IL}-18$, expressed in various cell types including keratinocytes and macrophages, was also shown to be involved in pruritus and could play a 
A

TLR2

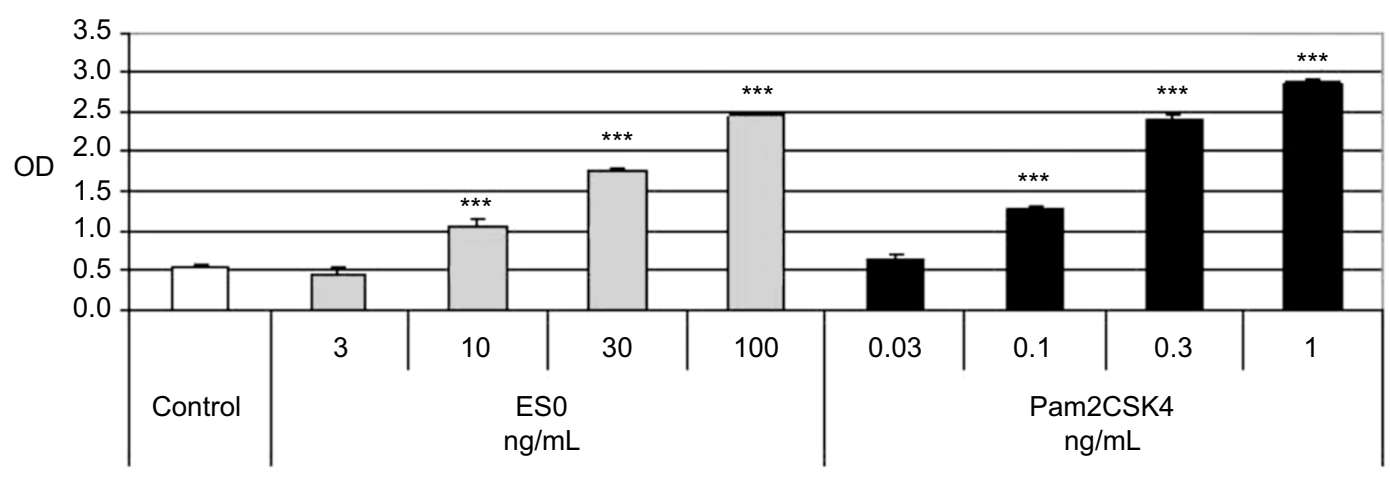

B

TLR4

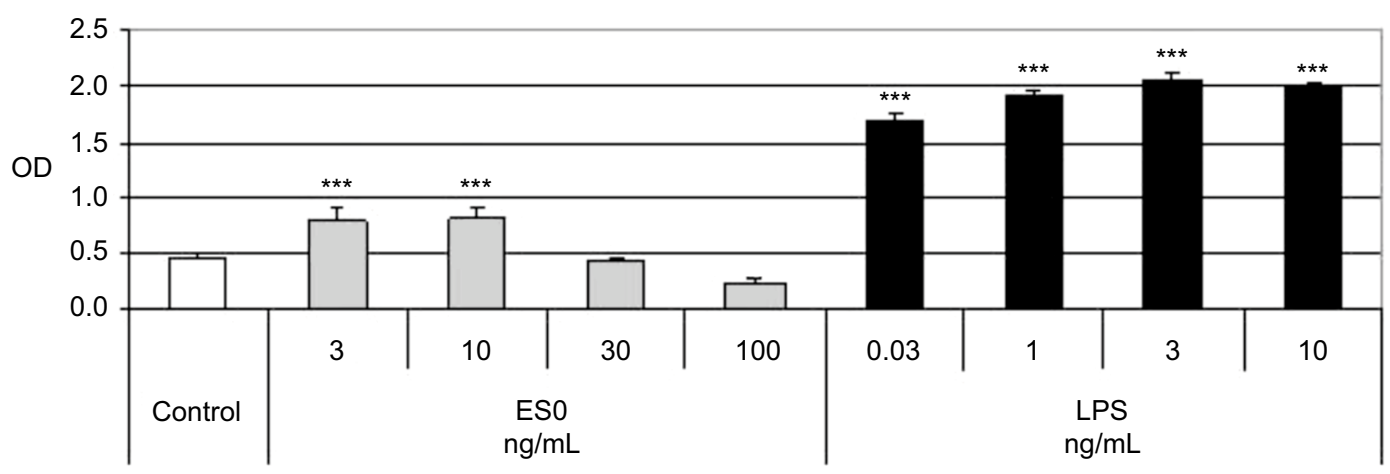

C

TLR5

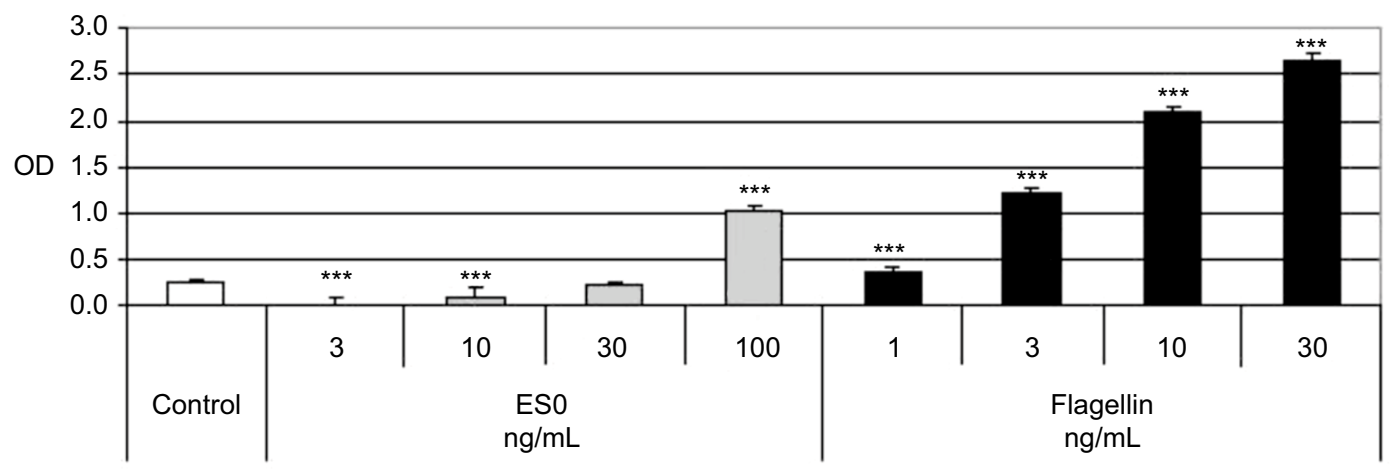

Figure 2 Spectrophotometric measurement of TLR2, TLR4, and TLR5 activation in HEK 293 cell lines.

Notes: HEK were stimulated with ES0 (3-100 ng/mL) or positive controls: Pam2CSK4 = TLR2 ligand $(\mathbf{A})$, LPS = TLR4 ligand $(\mathbf{B})$, and flagellin = TLR5 ligand $(\mathbf{C})$. ****P<0.00 I versus control; data are representative of three independent experiments.

Abbreviations: ESO, extract from A. dolomiae; HEK, human embryonic kidney; LPS, lipopolysaccharide; OD, optical density; TLR, toll-like receptor.

key role in the pathogenesis of $\mathrm{AD}$, in addition to its proinflammatory role. ${ }^{33,34}$ Chemokines, such as RANTES/CCL5, MCP-3/CCL7, thymus and activation-regulated chemokine (TARC)/CCL17, MIP-3a/CCL20, and MDC/CCL22, which were upregulated in the present model of $\mathrm{AD}$, were also found to be increased in AD skin lesions and might support leukocyte recruitment into the skin. ${ }^{35}$

By using this keratinocyte model mimicking an "ADlike" condition, it was showed that ES0 dose-dependently inhibited the expression of all of these proinflammatory mediators, including some associated with the severity of AD lesions, such as epidermal IL-18, which contributes to the development of $S$. aureus infection-associated AD and IL-8, recently shown to be significantly higher in the stratum corneum of severe lesions than in mild or moderate AD lesions. ${ }^{36-38} \mathrm{ES} 0$ almost completely inhibited IL-8 expression, which was highly expressed in the present AD model compared with normal keratinocytes. Finally, an 11-fold increase 

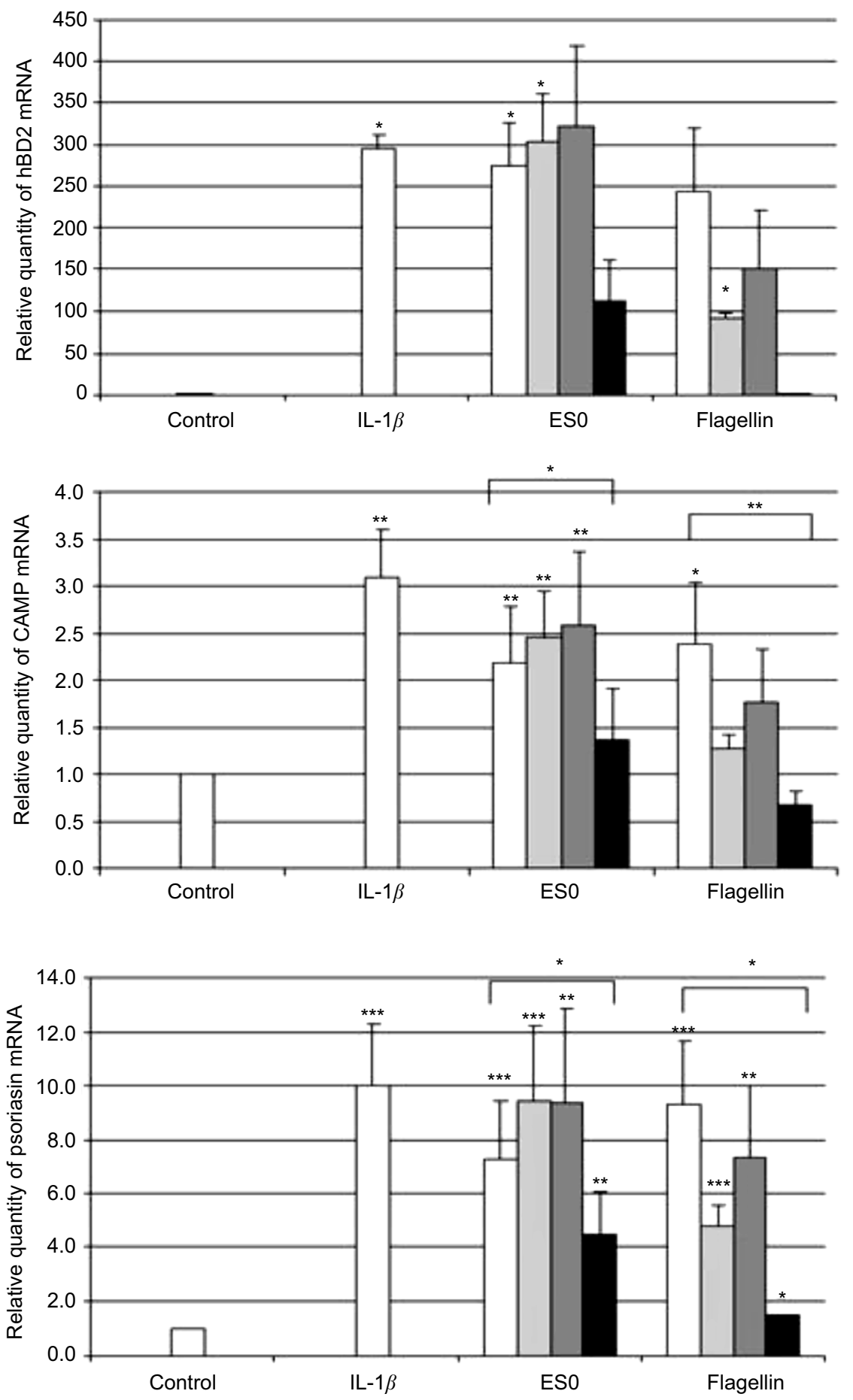

Figure 3 Relative quantity of hBD-2, CAMP, and psoriasin mRNA in NHK cells.

Notes: NHKs were stimulated by IL-I $\beta(20 \mathrm{ng} / \mathrm{mL}$, positive control), ESO $(6.5 \mu \mathrm{g} / \mathrm{mL})$, flagellin $(100 \mathrm{ng} / \mathrm{mL})$, or alone (negative control). Pretreatment was performed for I h with anti-TLR2 $(\square)$, anti-TLR4 $(\square)$, anti-TLR5 $(\square)(I \mu \mathrm{g} / \mathrm{mL})$, or without antibody $(\square)$ to test whether stimulation was blocked in ES0- and flagellin-treated samples; data are the mean of three independent experiments. $* P<0.05 ; * * P<0.0$ I; $* * * P<0.001$ versus control or comparator.

Abbreviations: CAMP, cathelicidin antimicrobial peptide; ESO, extract from A. dolomiae; hBD2, beta-defensin 2; NHK, normal human keratinocyte; TLR, toll-like receptor.

in involucrin expression was observed in this AD model following incubation with ES0 of $60 \mu \mathrm{g} / \mathrm{mL}$, as compared with a 1.1 -fold increase with DEX of $2 \mu \mathrm{M}$, showing the beneficial effect of ES0 on epidermal barrier integrity.

Another important feature of $\mathrm{AD}$ is pruritus, which is largely mediated by PAR-2 and also, as emerging evidence has shown, TSLP. ${ }^{39,40}$ PAR-2 plays a key role in AD pathogenesis: besides its role in inflammation and pruritus, it also acts as a sensor for exogenous proteases from various allergens, such as house dust mites, cockroaches, pollens, molds, and bacteria. ${ }^{39}$ Indeed, PAR-2 expression may be induced both by cutaneous inflammation and by these allergens. The 


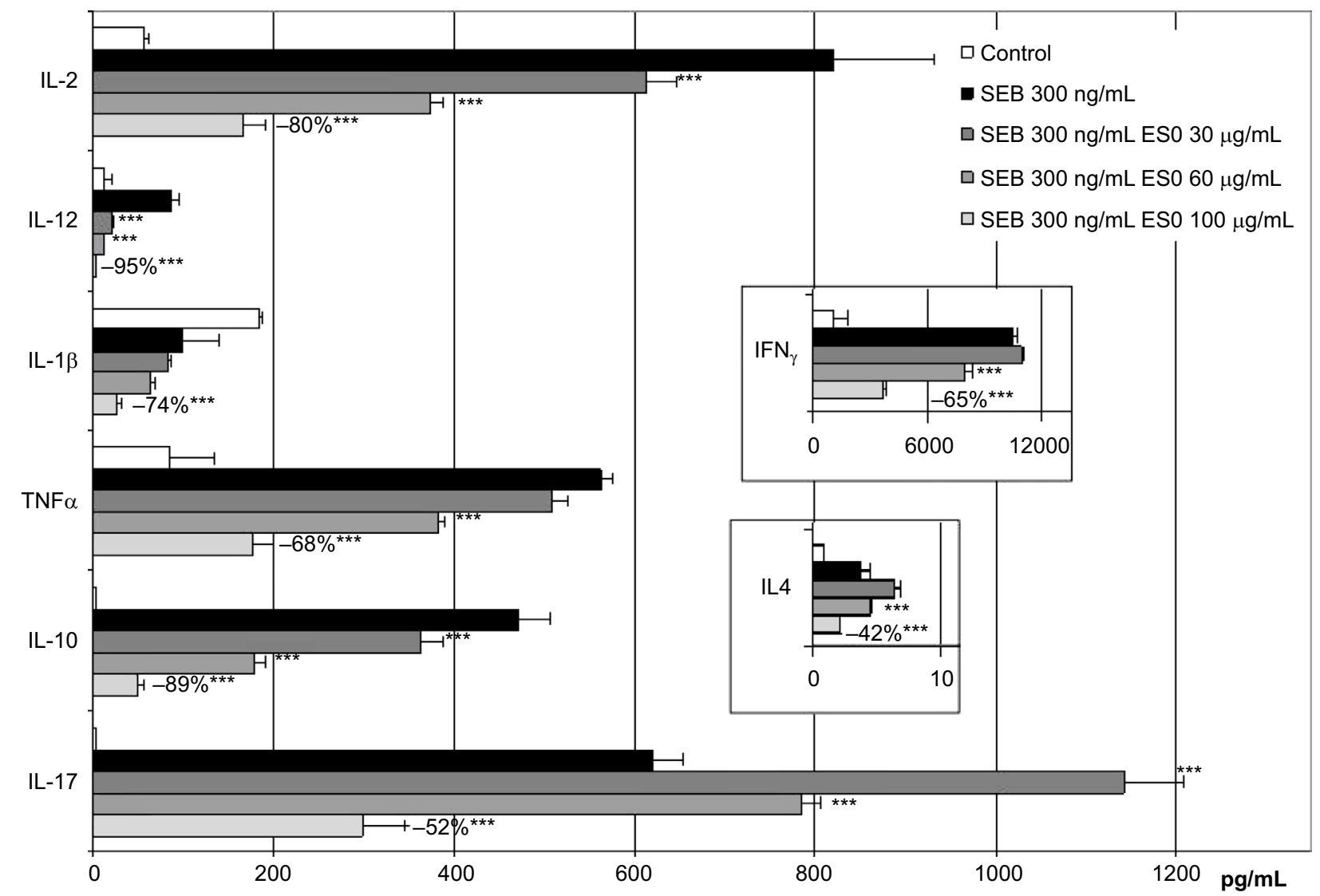

Figure 4 Lymphocyte stimulation by Staphylococcal enterotoxin B (SEB; $300 \mathrm{ng} / \mathrm{mL}$ ).

Notes: Dose effect of ESO $(30,60$, and $100 \mu \mathrm{g} / \mathrm{mL})$ on the production of Th1, Th2, and Th17 cytokines; data are representative of three independent experiments. ${ }^{* * *} P<0.00$ I versus SEB-treated cells.

Abbreviations: ESO, extract from A. dolomiae; IL, interleukin; SEB, Staphylococcal enterotoxin B; Th, T helper cell type; TNF $\alpha$, tumor necrosis factor alpha.

increased protease and PAR-2 activity in the lesional skin of patients with $\mathrm{AD}$ result in abnormal desquamation, alteration of the lipid barrier and antimicrobial barrier by degradation of lipid-processing enzymes and AMPs, respectively, and inflammation through activation of cytokines. As such, PAR-2 may represent a therapeutic target for the treatment of $\mathrm{AD} .{ }^{39}$ Importantly, in the present study, a marked inhibitory effect of ES0 on PAR-2 was observed, as shown by $50 \%$ inhibition of PAR-2 activation by SCTE in keratinocytes. ES0 could inhibit PAR-2 activation either by a direct inhibition on the receptor (antagonist effect) or by indirectly inhibiting SCTE (enzyme inhibition). As ES0 is also able to inhibit PAR-2 activated by its specific agonist peptide SLIGKV (data not shown), it could be suggested that ES0 has, at least, an antagonist activity on the PAR-2 receptor. Furthermore, until recently, TSLP was thought to indirectly trigger itch and AD by signaling between epithelial cells and innate immune cells. However, recently, it was shown that TSLP directly stimulates peripheral neurons to promote itch. ${ }^{40}$ It has been shown that PAR-2 activation increases expression of TSLP in cultured epithelial cells; in the present study, it was showed that ES0 inhibits the expression of TSLP. ${ }^{41}$ Thus, ES0 effectively modulates two targets that play a role in the genesis of pruritus in AD, TSLP, and PAR-2.

In addition, ES0 also displayed appreciable activity on innate immunity through the activation of TLRs, which are known to play a positive stimulatory role in innate immunity. ${ }^{7,8}$ Such an immunomodulatory effect of ES0 on TLR2, TLR4, and TLR5 activity without activation of other TLRs (TLR3, TLR7, TLR8, and TLR9; data not shown) in recombinant HEK 293 cell lines was demonstrated. These results suggest that ES0 could activate these three TLRs on normal skin cells that express these receptors. ${ }^{11,12,42,43}$ The combined activation of these three TLRs was shown to induce Th1 polarization synergistically via dendritic cells.$^{42}$ This could be of interest as acute $\mathrm{AD}$ is characterized by a skewed balance toward Th2, leading to inhibition of the production of major terminal differentiation proteins, such as involucrin, but also loricrin and filaggrin, and suppression of the expression of hBD-2 and hBD-3. ${ }^{13}$ Notably, several studies have shown that patients with $\mathrm{AD}$ have decreased expression and/or function of TLR2 in monocytes and macrophages. ${ }^{11,12}$ Recently, Kuo 
et al demonstrated that in cultured keratinocytes, the TLR2deficient mouse, and a human wound model, TLR2 functions include the preservation of tight junction integrity. ${ }^{43}$ This protective action would thus be reduced in patients with AD who express less TLR2, and deficient TLR2 responses would also lead to the persistence of pathogenic bacteria, such as $S$. aureus, on the skin surface and sustained inflammation. On the basis of these observations, Kuo et al concluded that strategies stimulating TLR2 expression or function might be promising in restoring epidermal integrity in $\mathrm{AD} .{ }^{43}$ In this context, the marked induction of TLR2, as well as TLR4 and TLR5, by ES0 is particularly valuable.

Another effect of ESO on innate immunity demonstrated in this study is the induction of expression of several AMPs (ie, CAMP, hBD-2, and psoriasin) in NHK. The effect of ES0 was markedly, but not completely inhibited by anti-TLR5, suggesting that the induction of AMPs by ES0 was mediated by activation of the TLR5 receptor. As TLR5 has been shown to be activated by bacterial flagella, the effect of ES0 on TLR5 could thus be explained by the fact that $A$. Dolomiae bears a polar flagellum. ${ }^{44}$ The effect of ES0 on AMP expression is of interest, as insufficient expression of several AMPs in AD was related to a higher susceptibility to $S$. aureus colonization, correlating with the severity of atopic lesions. ${ }^{45,46}$ There is evidence that AMPs are upregulated in $\mathrm{AD}$; however, in particular, the expression of CAMP and hBD-2 is not sufficiently upregulated in patients with $\mathrm{AD}$ to kill $S$. aureus. ${ }^{47}$ In addition to their antimicrobial function, hBD-2, LL-37 (CAMP), and psoriasin also contribute to host defenses against infections by their chemotactic activity. ${ }^{9,45}$ hBD-2 activates immature dendritic cells, inducing a strong Th1 response, LL-37 recruits inflammatory cells and triggers cytokine release through various mechanisms, and psoriasin also potentiates inflammation through its chemoattractant properties. ${ }^{45,48,49}$

Finally, ES0 displayed an immunomodulatory effect on lymphocyte cytokines by inhibiting Th1, Th2, and Th17 cytokine production (IL-2, IFN $\gamma$, IL-12, IL-1 $\beta$, TNF $\alpha /$ IL-4, IL-10/IL-17, respectively) in CD4+ lymphocytes. These cytokines play complex roles in $\mathrm{AD}{ }^{50}$ The relative absence of IL-17 production by Th17 in AD tissues was suspected to account for reduced AMP levels and a potential increase in the incidence of skin infections. ${ }^{50}$ However, the proinflammatory role of IL-17 was also established, suggesting that it could be useful to downregulate its expression. ${ }^{51}$ Th1 and Th2 cytokines have been shown to be involved in the development of AD. Therefore, downplaying the expression of both Th2 and Th1 cytokines, as shown in experimental models, might be valuable in controlling $\mathrm{AD} .^{13}$

\section{Conclusion}

In conclusion, data from the present study show that ES0, an $A$. dolomiae extract, has marked regulatory activity on keratinocyte inflammation, particularly PAR-2-dependent pruritus-associated inflammation, skin barrier impairment, and innate and adaptive immune responses. These effects on various pathophysiological mechanisms of $A D$ suggest the potential value of this extract in topical preparations designed to regulate $\mathrm{AD}$. Moreover, a recent study showed that ES0 counteracts the effects of cutaneous $S$. aureus secretome isolated from atopic children on CD4+T-cell activation. ${ }^{52}$ Owing to the role of $S$. aureus colonization in driving inflammation in $\mathrm{AD}$, the immunosuppressive property of ESO might be useful to reduce disease severity. This study, together with the results, showed very interesting activities of ES0 on different parameters implicated on AD.

Moreover, clinical studies were performed in infants, children, and adults with AD in order to assess the efficacy of an ES0-based cream in vivo; these results have been recently published and confirmed that an ES0-based cream applied twice daily decreased the SCORing Atopic Dermatitis ${ }^{53}$ and pruritus after 28 days of application. ${ }^{54}$ Furthermore, this ES0-based cream protected the skin from $S$. aureus proliferation and preserved microflora biodiversity. These results confirmed the interesting activities of $A$. dolomiae extract on adjunctive treatment of AD inflammatory and pruritic lesions.

Indeed, as proposed by Guttman-Yassky et al, "a combination of more than one biologic agent or a biologic agent that targets more than one immunologic factor or cell type might be the best approach to treating AD." 50

\section{Acknowledgments}

The authors thank Françoise Nourrit-Poirette and Marielle Romet from Santé Active Edition and Nila Bhana, Content Ed Net, who provided assistance in medical writing. This work was supported by Pierre Fabre Group.

\section{Disclosure}

The authors are employees of Pierre Fabre Dermo-Cosmétique, France. The authors report no other conflicts of interest in this work.

\section{References}

1. Oyoshi MK, He R, Kumar L, Yoon J, Geha RS. Cellular and molecular mechanisms in atopic dermatitis. Adv Immunol. 2009;102:135-226.

2. Bieber T. Atopic dermatitis. N Engl J Med. 2008;358(14):1483-1494.

3. Boguniewicz M, Leung DY. Atopic dermatitis: a disease of altered skin barrier and immune dysregulation. Immunol Rev. 2011;242(1):233-246. 
4. Rattenholl A, Steinhoff M. Proteinase-activated receptor-2 in the skin: receptor expression, activation and function during health and disease. Drug News Perspect. 2008;21(7):369-381.

5. Pastore S, Mascia F, Girolomoni G. The contribution of keratinocytes to the pathogenesis of atopic dermatitis. Eur J Dermatol. 2006;16(2):125-131.

6. Gutowska-Owsiak D, Ogg GS. The epidermis as an adjuvant. J Invest Dermatol. 2012;132(3 Pt 2):940-948.

7. Iwasaki A, Medzhitov R. Toll-like receptor control of the adaptive immune responses. Nat Immunol. 2004;5(10):987-995.

8. Manicassamy S, Pulendran B. Modulation of adaptive immunity with Toll-like receptors. Semin Immunol. 2009;21(4):185-193.

9. Hata TR, Gallo RL. Antimicrobial peptides, skin infections, and atopic dermatitis. Semin Cutan Med Surg. 2008;27(2):144-150.

10. Mandron M, Ariès MF, Brehm RD, Tranter HS, Acharya KR, Charveron M, Davrinche C. Human dendritic cells conditioned with Staphylococcus aureus enterotoxin B promote $\mathrm{TH} 2$ cell polarization. J Allergy Clin Immunol. 2006;117(5):1141-1147.

11. Hasannejad H, Takahashi R, Kimishima M, Hayakawa K, Shiohara T. Selective impairment of Toll-like receptor 2-mediated proinflammatory cytokine production by monocytes from patients with atopic dermatitis. J Allergy Clin Immunol. 2007;120(1):69-75.

12. Niebuhr M, Lutat C, Sigel S, Werfel T. Impaired TLR-2 expression and TLR-2-mediated cytokine secretion in macrophages from patients with atopic dermatitis. Allergy. 2009;64(11):1580-1587.

13. Yamanaka K, Mizutani H. The role of cytokines/chemokines in the pathogenesis of atopic dermatitis. Curr Probl Dermatol. 2011;41:80-92.

14. Koga C, Kabashima K, Shiraishi N, Kobayashi M, Tokura Y. Possible pathogenic role of Th17 cells for atopic dermatitis. J Invest Dermatol. 2008;128(11):2625-2630.

15. Kim BE, Leung DY, Boguniewicz M, Howell MD. Loricrin and involucrin expression is down-regulated by Th2 cytokines through STAT-6. Clin Immunol. 2008;126(3):332-337.

16. Pigatto $P$. The efficacy of Avène thermal spring water in light to moderate atopic dermatitis. Ann Dermatol Venereol. 2005;132(10 Pt 2): 6S16-6S18.

17. Giannetti A. The hydrotherapy centre in Avène-les-bains. A controlled study in atopic dermatitis. Ann Dermatol Venereol. 2005;132(10 Pt 2):6S12-6S15.

18. Taieb C, Sibaud V, Merial-Kieny C. Impact of Avène hydrotherapy on the quality of life of atopic and psoriatic patients. J Eur Acad Dermatol Venereol. 2011;25(Suppl 1):24-29.

19. Casas C, Ribet V, Alvarez-Georges S, Sibaud V, Guerrero D, Schmitt AM, Redoules D. Modulation of interleukin-8 and staphylococcal flora by Avène hydrotherapy in patients suffering from chronic inflammatory dermatoses. J Eur Acad Dermatol Venereol. 2011;25(Suppl 1):19-23.

20. Bourrain M, Ribet V, Calvez A, Lebaron P, Schmitt AM. Balance between beneficial microflora and Staphylococcus aureus colonisation: in vivo evaluation in patients with atopic dermatitis during hydrotherapy. Eur J Dermatol. 2013;23(6):786-794.

21. Portalès P, Ariès MF, Licu D, et al. Immunomodulation induced by Avène spring water on Th1- and Th2-dependent cytokine production in healthy subjects and atopic dermatitis patients. Skin Pharmacol Appl Skin Physiol. 2001;14(4):234-242.

22. Merial-Kieny C, Castex-Rizzi N, Selas B, Mery S, Guerrero D. Avène Thermal Spring Water: an active component with specific properties. J Eur Acad Dermatol Venereol. 2011;25(Suppl 1):2-5.

23. Bourrain M, Villette C, Nguyen T, Lebaron P. Aquaphilus dolomiae gen. nov., sp. nov., isolated from a deep aquifer. Vie Milieu. 2012;62:191-195.

24. Castex-Rizzi N, Galliano MF, Aries MF, et al. In vitro approaches to pharmacological screening in the field of atopic dermatitis. $\mathrm{Br} J \mathrm{Der}$ matol. 2014;170(Suppl 1):12-18.

25. Kinoshita H, Takai T, Le TA, et al. Cytokine milieu modulates release of thymic stromal lymphopoietin from human keratinocytes stimulated with double-stranded RNA. J Allergy Clin Immunol. 2009;123(1):179-186.
26. Bernard FX, Morel F, Camus M, et al. Keratinocytes under fire of proinflammatory cytokines: bona fide innate immune cells involved in the physiopathology of chronic atopic dermatitis and psoriasis. J Allergy (Cairo). 2012;2012:718725.

27. Bao L, Shi VY, Chan LS. IL-4 up-regulates epidermal chemotactic, angiogenic, and pro-inflammatory genes and down-regulates antimicrobial genes in vivo and in vitro: relevant in the pathogenesis of atopic dermatitis. Cytokine. 2013;61(2):419-425.

28. Mosmann T. Rapid colorimetric assay for cellular growth and survival: application to proliferation and cytotoxicity assays. J Immunol Methods. 1983;65(1-2):55-63.

29. Boukamp P, Petrussevska RT, Breitkreutz D, Hornung J, Markham A, Fusenig NE. Normal keratinization in a spontaneously immortalized aneuploid human keratinocyte cell line. J Cell Biol. 1988;106(3):761-771.

30. Casas C, Ginisty H, Alvarez-Georges S, et al. Molecular characterization of inflammation and Staphylococcus aureus colonization of involved skin of atopic dermatitis patients. A non-invasive approach. Skin Pharmacol Physiol. 2008;21(5):260-268.

31. Soumelis V, Reche PA, Kanzler H, et al. Human epithelial cells trigger dendritic cell mediated allergic inflammation by producing TSLP. Nat Immunol. 2002;3(7):673-680.

32. Leyva-Castillo JM, Hener P, Jiang H, Li M. TSLP produced by keratinocytes promotes allergen sensitization through skin and thereby triggers atopic march in mice. J Invest Dermatol. 2013;133(1):154-163.

33. Konishi H, Tsutsui H, Murakami T, et al. IL-18 contributes to the spontaneous development of atopic dermatitis-like inflammatory skin lesion independently of IgE/stat6 under specific pathogen-free conditions. Proc Natl Acad Sci U S A. 2002;99(17):11340-11345.

34. Nakanishi K, Yoshimoto T, Tsutsui H, Okamura H. Interleukin-18 regulates both Th1 and Th2 responses. Annu Rev Immunol. 2001;19:423-474.

35. Homey B, Steinhoff M, Ruzicka T, Leung DY. Cytokines and chemokines orchestrate atopic skin inflammation. J Allergy Clin Immunol. 2006;118(1):178-189.

36. Inoue Y, Aihara M, Kirino M, et al. Interleukin-18 is elevated in the horny layer in patients with atopic dermatitis and is associated with Staphylococcus aureus colonization. Br J Dermatol. 2011;164(3):560-567.

37. Tsutsui H, Mizutani H, Nakanishi K. Contribution of interleukin 18 to the development of infection-associated atopic dermatitis. Curr Probl Dermatol. 2011;41:93-103.

38. Amarbayasgalan T, Takahashi H, Dekio I, Morita E. Interleukin- 8 content in the stratum corneum as an indicator of the severity of inflammation in the lesions of atopic dermatitis. Int Arch Allergy Immunol. 2013;160:63-74.

39. Lee SE, Jeong SK, Lee SH. Protease and protease-activated receptor-2 signaling in the pathogenesis of atopic dermatitis. Yonsei Med J. 2010;51(6):808-822.

40. Wilson SR, Thé L, Batia LM, et al. The epithelial cell-derived atopic dermatitis cytokine TSLP activates neurons to induce itch. Cell. 2013;155(2):285-295.

41. Moniaga CS, Jeong SK, Egawa G, et al. Protease activity enhances production of thymic stromal lymphopoietin and basophil accumulation in flaky tail mice. Am J Pathol. 2013;182(3):841-851.

42. Napolitani G, Rinaldi A, Bertoni F, Sallusto F, Lanzavecchia A. Selected Toll-like receptor agonist combinations synergistically trigger a $\mathrm{T}$ helper type 1-polarizing program in dendritic cells. Nat Immunol. 2005; 6(8):769-776.

43. Kuo IH, Carpenter-Mendini A, Yoshida T, et al. Activation of epidermal toll-like receptor 2 enhances tight junction function: implications for atopic dermatitis and skin barrier repair. J Invest Dermatol. 2013;133(4): 988-998.

44. Hayashi F, Smith KD, Ozinsky A, et al. The innate immune response to bacterial flagellin is mediated by Toll-like receptor 5. Nature. 2001;410(6832):1099-1103.

45. Nakatsuji T, Gallo RL. Antimicrobial peptides: old molecules with new ideas. J Invest Dermatol. 2012;132(3 Pt 2):887-895.

46. Schittek B. The antimicrobial skin barrier in patients with atopic dermatitis. Curr Probl Dermatol. 2011;41:54-67. 
47. Ong PY, Ohtake T, Brandt C, et al. Endogenous antimicrobial peptides and skin infections in atopic dermatitis. N Engl J Med. 2002;347(15): 1151-1160.

48. Biragyn A, Ruffini PA, Leifer CA, et al. Toll-like receptor 4-dependent activation of dendritic cells by beta-defensin 2. Science. 2002;298(5595): 1025-1029.

49. Wolf R, Howard OM, Dong HF, et al. Chemotactic activity of S100A7 (Psoriasin) is mediated by the receptor for advanced glycation end products and potentiates inflammation with highly homologous but functionally distinct S100A15. J Immunol. 2008;181(2):1499-1506.

50. Guttman-Yassky E, Nograles KE, Krueger JG. Contrasting pathogenesis of atopic dermatitis and psoriasis - part II: immune cell subsets and therapeutic concepts. JAllergy Clin Immunol. 2011;127(6):1420-1432.
51. Mills KH, Dungan LS, Jones SA, Harris J. The role of inflammasomederived IL-1 in driving IL-17 responses. J Leukoc Biol. 2013;93(4): 489-497.

52. Martin H, Laborel-Préneron E, Fraysse F, Nguyen T, Schmitt AM, Redoulès D, Davrinche C. Aquaphilus dolomiae extract counteracts the effects of cutaneous $\mathrm{S}$. aureus secretome isolated from atopic children on CD4+ T cell activation. Pharm Biol. 2016;14:1-4.

53. [No authors listed]. Severity scoring of atopic dermatitis: the SCORAD index. Consensus Report of the European Task Force on Atopic Dermatitis. Dermatology. 1993;186(1):23-31.

54. Bianchi P, Theunis J, Casas C, et al. Effects of a new emollient-based treatment on skin microflora balance and barrier function in children with mild atopic dermatitis. Pediatr Dermatol. 2016;33(2):165-71. 


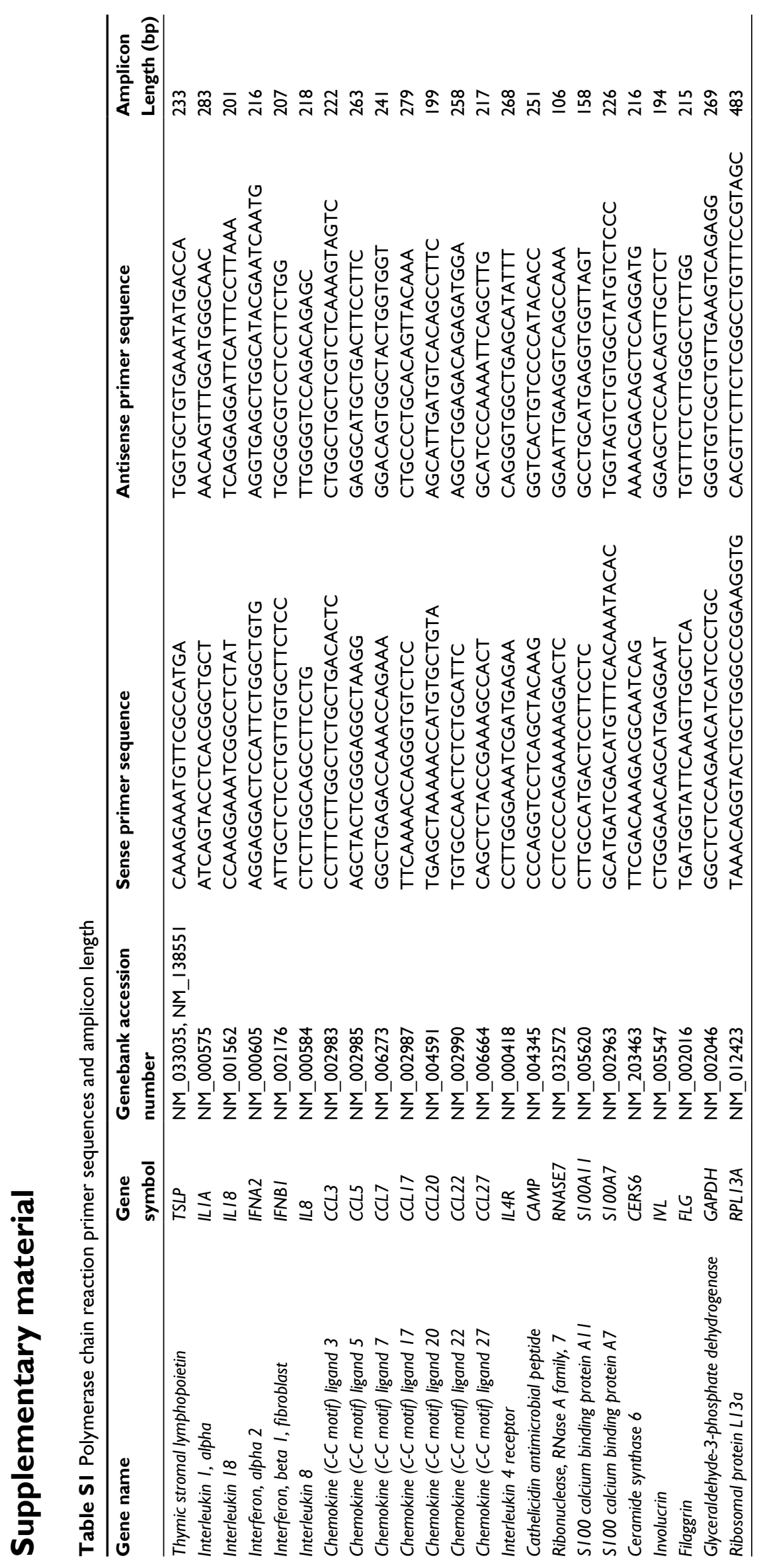




\section{Publish your work in this journal}

Clinical, Cosmetic and Investigational Dermatology is an international, peer-reviewed, open access, online journal that focuses on the latest clinical and experimental research in all aspects of skin disease and cosmetic interventions. This journal is included on PubMed. The manuscript management system is completely online

Submit your manuscript here: https://www.dovepress.com/clinical-cosmetic-and-investigational-dermatology-journal

and includes a very quick and fair peer-review system, which is all easy to use. Visit http://www.dovepress.com/testimonials.php to read real quotes from published authors 